\title{
OBRAZ ZIEMI OJCZYSTEJ W TWÓRCZOŚCI ARTYSTÓW POLSKIEGO LONDYNU*
}

Panie Dziekanie, Wysoka Rado, Szanowni Państwo, Drodzy Studenci.

Wybitny klasyk literatury polskiej XX w., londyńczyk, Kazimierz Wierzyński, w wierszu pt. Ktokolwiek jesteś bez ojczyzny — pisał:

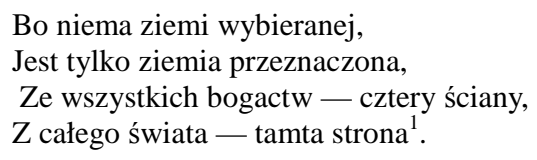

Dla rzeszy Polaków — politycznych uchodźców po II wojnie światowej, w tym dla artystów i poetów, ojczyzna, którą znali przed 1939 r., przestała istnieć. Jak pisał Adam Walaszek:

przecięta linią Curzona i w swojej dawnej części całkowicie niedostępna, albo nieistniejąca ze względu na zmieniony ustrój, Polska się rozpłynęła. Wyrwano im ją. Na emigracji, skoro powrót był niemożliwy, należało przenieść ojczyznę w miejsce zamieszkania ${ }^{2}$.

Plastyka tak zwanego polskiego Londynu — największej po II wojnie światowej, polskiej diaspory artystycznej w Europie, obejmująca malarstwo, grafikę i rzeźbę, W stosunku do polskiej literatury powstałej w Wielkiej Brytanii, rozpoznana jest nieporównywalnie gorzej. Proces jej właściwego umiejscowienia w polskiej historii sztuki,

\footnotetext{
${ }^{*}$ Wykład inauguracyjny wygłoszony w dniu 6 października 2011 r., podczas inauguracji roku akademickiego Wydziału Historycznego UMK w Toruniu.

${ }^{1}$ Wiersz z tomu Róża wiatrów (Nowy Jork 1942); cyt za: K. Wierzyński, Poezje zebrane, Londyn-Nowy Jork [1958], s. 347.

${ }^{2}$ Por.: A. Walaszek, Polska diaspora, [w:] Polska diaspora, red. nauk. A. Walaszek, aut. D. Bartkowiak [et al.], Kraków 2001, s. 17.
} 
rozpoczął się dopiero przed kilkunastoma laty, dzięki między innymi takim jednostkom badawczym, jak powołane w UMK Archiwum Emigracji.

Liczbę Polaków, jedynie przypomnę, zamieszkałych w Wielkiej Brytanii po ustaniu powojennych ruchów migracyjnych w końcu lat 40. XX w., szacuje się na około 150 tys. Największym skupiskiem Polaków w Anglii stał się Londyn, w którym osiedliło się około 30 tys. naszych Rodaków.

Wbrew potocznym wyobrażeniom, w powojennej fali emigracji do Wielkiej Brytanii wcale nie dominowali przedstawiciele inteligencji. Po 1945 r., co warto również przypomnieć, blisko 70\% Polaków przybyłych na Wyspy Brytyjskie, pochodziło z Kresów. Urodzili się lub mieszkali do 1939 r. w województwach wschodnich II Rzeczypospolitej. Z tej ,fali” emigracji wywodziła się, poza politykami i oficerami, największa grupa publicystów, pisarzy, poetów, uczonych, artystów scenicznych oraz plastyków polskiego Londynu. To oni, słowem pisanym i kodem artystycznym dzieł plastycznych, uświadamiali współrodakom, że pamięć jednostkowa dotycząca ziemi przodków, powinna przekształcać się w pamięć zbiorową. Obrazy Starego Kraju, jego pejzażu i wyobrażeń o nim, stanowiły bardzo ważny element przekształcającej się świadomości członków polskiej grupy etnicznej osiadłej w Wielkiej Brytanii.

Szanowni Państwo, zanim pochylimy się nad plastyką polskiego powojennego Londynu, warto przypomnieć, iż w obszarze polskiej literatury, to przede wszystkim Kresy, zwłaszcza północno-wschodnie, wydały na emigracji, dorobek obejmujący główne kategorie piśmiennictwa. W powieściach polskich emigrantów, poczynając od Józefa Mackiewicza, poprzez Floriana Czarnyszewicza, Michała Kryspina Pawlikowskiego a na Czesławie Miłoszu kończąc, panorama Kresów, jak pisała Nina Taylor, zarysowana została ,z realizmem i autentyzmem wręcz rewelacyjnym"3.

Zręby polskiego artystycznego (w sensie - plastycznego) Londynu, zaczęły kształtować się jeszcze przed wybuchem II wojny światowej. Pierwszy na Wyspy Brytyjskie przyjechał w 1935 r. Feliks Topolski. Za nim, w dwa lata później Marek Żuławski, który w pewnym sensie osiadł i pozostał w stolicy Anglii przypadkowo (tracąc paszport w jednym z nocnych lokali na londyńskim Soho). Przed wojną dołączył do nich Henryk Gotlib, a już w czasie wojny, Zdzisław Ruszkowski, Jankiel Adler, Franciszka i Stefan Themersonowie, Adam Kossowski oraz Tadeusz Piotr Potworowski, Wojciech Jastrzębowski (rektor przedwojennej ASP w Warszawie) i Jan Wieliczko.

Ale dopiero po 1947 r., najbardziej jednorodną grupę polskich artystów-malarzy w Londynie, stworzyli studenci Szkoły Malarstwa Sztalugowego. Jej korzenie sięgają roku 1945, kiedy to dzięki przychylności gen. Władysława Andersa, przy 2. Korpusie stacjonującym wówczas we Włoszech, profesor Marian Bohusz-Szyszko, zorganizował Szkołę Malarską, w skład której weszli artyści polscy w żołnierskich mundurach.

Dodam jedynie, iż artyści ci stanowili zaledwie niewielką część polskiej powojennej diaspory artystycznej w Londynie. Prowadzone w tym zakresie badania, wyprowadzają na światło dzienne około 800 artystów plastyków, spośród których co najmniej stu chętnie — jako wybitnych malarzy brytyjskich — przypisuje sobie angielska historia sztuki XX w., my zaś — w opracowaniach poświęconych polskiej sztuce XX w., zaledwie lakonicznie wspominamy najwyżej o kilku lub kilkunastu z nich.

Mistrzem w rozbudzaniu talentów artystycznych w Londynie był, urodzony w 1901 r. w Trokiennikach na Wileńszczyźnie Marian Bohusz-Szyszko, który zapamiętane obrazy kraju rodzinnego utrwalał na płótnach przez całe artystyczne życie, do

\footnotetext{
${ }^{3}$ N. Taylor, Kresy Pótnocno-Wschodnie, [w:] Leksykon kultury polskiej poza krajem od roku 1939, t. 1, pod red. K. Dybciaka i Z. Kudelskiego, Lublin 2000, s. 205.
} 
śmierci w 1995 r. M.in. w Tece Wileńskiej, opublikowanej przez oficynę Gliwów w 1953 r., przypominał polskim londyńczykom pejzaże ziemi wileńskiej — sylwety kościołów Wilna, przedstawienia Góry Trzech Krzyży, rysunki zaułków i uliczek oraz dziedzińców i obserwatorium Uniwersytetu Stefana Batorego. Sam pejzaż, a zwłaszcza tzw. „wnętrza lasu”, były częstym tematem jego obrazów olejnych, które powstały w okresie, kiedy artysta przebywał w Szkocji, a tamtejsze lasy (jak wspominał) przypominały mu litewskie puszcze.

Jedną ze studentek i absolwentek Studium Malarstwa Sztalugowego BohuszaSzyszki (to - dla zachowania obecnie modnego parytetu!), która swój cykl rysunków w tece zatytułowanej Wilno poświęciła rodzinnemu miastu, była Halina Sukiennicka. Jak mawiał jej nauczyciel, była to malarka ,późnego powołania”. Po wojnie, w warunkach angielskich, pozbawiona możliwości wykonywania zawodu prawnika, w drugiej połowie życia wybrała drogę kariery artystycznej. Wileńskie kompozycje Sukiennickiej były wspomnieniami ,wyrażonymi kreską i plamą”, rejestrującymi obrazy, które w czasie ich powstawania były dostępne jedynie w pamięci byłej adwokat.

Kurs Szkoły Malarstwa Sztalugowego ukończyła także inna wilnianka - Halima Nałęcz, przed wojną uczennica profesora Uniwersytetu Stefana Batorego - Michała Rouby. Po przejściu szlaku 2. Korpusu, Nałęcz na początku lat 50. XX w. studiowała w Paryżu, w pracowni Henri Closona, a następnie u Bohusza w Londynie. Po okresie fascynacji abstrakcją, różnorodność doświadczeń i tradycji warsztatowych, doprowadziła malarkę do ponownego odkrycia przyrody (Rediscovery of Nature - co bardzo podkreślali i doceniali brytyjscy krytycy sztuki). Uwagę Halimy Nałęcz zaczęła coraz bardziej przyciągać natura. Jak pisała krytyczka sztuki Alicja Drwęska:

Te krajobrazy z bajki i marzeń, opiewają urodę natury. W tych egzotycznych przedstawieniach, w owych dżunglach fantastycznie rozkwitłych kwiatów, rozbrzmiewają dalekie, lecz dość głośne echa polskiego folkloru ${ }^{4}$.

Na Halimie Nałęcz piętno „bohuszowego doświadczenia” się nie wyczerpuje. Obrazy olejne, o silnym ładunku tęsknoty za krainami dzieciństwa i młodości, tworzyło blisko 50 uczniów Bohusza.

Jednym z najmłodszych, jest Wojciech Falkowski, który od 1940 r. jako zesłaniec, na Syberii poznał piekło wegetacji na nieludzkiej ziemi. Stąd, z armią Andersa, przeszedł szlak przez Teheran, Bliski Wschód i Afrykę.

Na wyobraźnię artystyczną Falkowskiego, szczególny wpływ miał jego pobyt w Tanzanii. Bogata w kolory otaczająca młodego artystę afrykańska przyroda, intensywne światło i rozedrgane powietrze - to doświadczenia, które znalazły odbicie w palecie barwnej dzieł przyszłego malarza. Ale nie pejzaż afrykański stał się tematem prac malarskich artysty. Obrazy Falkowskiego, takie jak Wspomnienie z dzieciństwa, Za polska wioska czy Polski pejzaż II, to owoce stałej tęsknoty artysty za rodzinną grodzieńszczyzną.

W Londynie tworzyli także plastycy, których możemy nazwać „artystami osobnymi”, w rozumieniu tego terminu, raczej jako - pracujący na uboczu polskiego środowiska artystycznego — niż zajmujący się sztuką trudniej podlegająca klasyfikacjom. Należy do nich m.in. urodzony we Lwowie Marian Kratochwil. W szkicach i rysunkach artysty, zarówno tych przedwojennych jak i powojennych, oraz w dziesiątkach jego olejnych płócien — pejzaż ziemi ojczystej zdaje się być zawsze tematem bardzo ważnym.

\footnotetext{
${ }^{4}$ A. Drwęska, Odnalezienie natury, Tydzień Polski 1967 nr 48, s. 8.
} 
Ale czy tylko pejzaż polski?

Szanowni Państwo. W polskiej literaturze emigracyjnej — raz jeszcze odwołam się do niej — poza polskim pejzażem pojawiać się zaczął również pejzaż obcy. Na proces ten — już w 1944 r. zwracał uwagę Jan Bielatowicz, we wstępie pod tytułem Imperium polskiej poezji, zamieszczonym w jeszcze żołnierskiej antologii poetyckiej Azja i Afry$k a$, pisząc:

Po raz pierwszy w historii literatury polskiej, pojawił się w dzikim przepychu Ural - przesączony przez serca polskie, pojawiły się śnieżne dale polarnej Rosji. Przypomniał się Sybir, tajga i wschodnie krańce Azji. Gorącym słońcem buchnęły stepy uzbeckie i kazachstańskie. Seledynem nadziei olśniło Morze Kaspijskie i rozwarły się dalekie drogi przez pustynie, góry, oazy i morza: Persji, Iraku, Kurdystanu, Syrii, Libanu, Palestyny, Egiptu. Mórz: Śródziemnego, Czerwonego, Oceanu Indyjskiego i Zatoki Perskiej ${ }^{5}$.

Tak też w twórczości plastycznej londyńczyków, odnajdujemy owe pejzaże odmienne i dalekie od pozostawionych na zawsze widoków i wspomnień rodzinnej ziemi. Przywieźli je ze sobą na Wyspy Brytyjskie przede wszystkim żołnierze-artyści, którzy

służyli w 2. Korpusie.

Niech zobrazują ten proces dwie artystyczne sylwetki.

Przesiąkniętą kolejami losu tułacza i doświadczeniami wojennymi, jest twórczość Andrzeja Kuhna, który ze Lwowa w 1940 r. został deportowany w głąb Rosji, skąd przedostał się do Persji oraz na Bliski Wschód.

Na charakter malarskiej oraz rzeźbiarskiej twórczości tego londyńczyka, złożyły się — z jednej strony, wszechobecny na jego płótnach, bajkowy, silnie osadzony w klimacie Orientu, oszczędny w środkach wyrazu, nastrój niedopowiedzenia i tajemniczości; z drugiej zaś, wyraźnie świadomie kultywowany wątek inspiracji polską ludowością i twórczością naiwną, którą artysta znał z twórczości swojego ojca. Obcując z obrazami Kuhna, jak pisała Alicja Skalska, ,odzyskujemy utracony wiek niewinności, zanurzony w świat baśni, dziecięcej wyobraźni i marzeń”,

Na Środkowy i Bliski Wschód wojenne losy rzuciły także, urodzonego w 1918 r. w Krakowie, Stanisława Frenkla. Artysta ten przede wszystkim przez człowieka ukazywał swój własny świat. Świat dramatyczny i szyderczy, który pokrewny jest w pewnym sensie makabrycznym tworom Francisa Bacona. Jego malarstwo jest ,theatrum życia” — prawdziwym ludzkim bestiariuszem, jakimś „tympanonem — mówił Stanisław Rodziński — prowadzącym w tajemnice naszego czasu" "7. Przez ludzkie tłumy czy też pojedynczą sylwetkę, sceny bliskie fantasmagoriom Goyi — Frenkiel parafrazował swoje wspomnienia z dzieciństwa. Na płótnach malarza pełno jest scen, z przywoływanej przez artystę atmosfery rodzinnego Krakowa, jego korowodów, maskarad, obchodów rocznicowych, pantomimy i zapustnej zabawy, ale — uwzględniając cały dorobek malarza - przeważa w nim szereg, często niejednoznacznych scen, które artysta rejestrował na Bliskim Wschodzie i w Europie, po wyjściu ze Związku Sowieckiego. Na płótnach Frenkla spotykają się jednocześnie akrobaci i prostytutki — wyła-

\footnotetext{
${ }^{5}$ Azja i Afryka. Antologia poezji polskiej na Środkowym Wschodzie, oprac. J. Bielatowicz, Palestyna 1944, s. 8.

${ }^{6}$ A. Skalska, Wiek niewinności. Malarstwo Andrzeja Kuhna, Dziennik Polski i Dziennik Żołnierza 1977 nr 120, s. 6.

${ }^{7}$ Por.: J. W. Sienkiewicz, Królewski dar dla Muzeum Uniwersyteckiego. Dzieła Stanisława Frenkla w Toruniu, Głos Uczelni 2010 nr 11, s. 20-21.
} 
niające się z krętych zaułków Kairu, Jafy, Bejrutu i Stambułu, uczestnicy hiszpańskich procesji religijnych i podejrzane tancerki nocnych lokali.

Nie sposób w tym miejscu nie poczynić dygresji, zachęcającej Państwa do obejrzenia ponad 200 dzieł olejnych tego malarza, które od niespełna roku znajdują się w zbiorach Muzeum Uniwersyteckiego UMK, i stanowią największą kolekcję dzieł tego artysty w świecie.

Kończąc naszą ekspresową podróż po panoramie plastyki polskiej na emigracji, pragnę odwołać się do postaw twórczych dwóch, bodajże największych, mistrzów polskiego Londynu.

Do Polski, i to nie tylko w wyobraźni, powracał wspomniany na początku wystąpienia, Feliks Topolski. Ten globtroter i kosmopolita z wyboru, będąc obywatelem świata, prawie nadwornym malarzem na brytyjskim dworze królewskim, nie przestał być Polakiem. Wyjeżdżając po wojnie z Londynu do kraju rodzinnego, za każdym razem, w swoim szkicowniku, przywoził nowe obrazy polskiej przyrody i polskich miast. Nigdy nie zaciążyły na Topolskim kompleksy wygnańca. Nie manifestował swojej polskości — to prawda, ale i nigdy jej nie ukrywał. „Sprawa polska” jako temat rysunków obchodziła go tyle samo, co wydarzenia w Angoli, Ugandzie, Chile czy w Chinach. Kiedy jednak poruszał tematy polskie, mówił o nich bez przesądów, uprzedzeń, czy naiwnej wiary. I tak, jak dla wielu artystów na emigracji, reprezentujących postawę tak zwanego Londynu niezłomnego (jak chociażby w przypadku Mariana Bohusza-Szyszki) — dla którego polskość była obsesją, to dla Feliksa Topolskiego — stała się inspiracją i odskocznią.

W swojej twórczości, zarówno malarskiej jak i pisarskiej, do wspomnień i obrazów ziemi ojczystej powracał także Marek Żuławski, który tak jak Topolski znał Polskę powojenną z autopsji i to nie tylko jako malarz, ale także jako taternik i wielki miłośnik gór i Zakopanego. I chociaż centralnym punktem zainteresowań Żuławskiego był jak u Frenkla - przede wszystkim człowiek i jego kondycja we współczesnym świecie, to wątek patriotyczny wyraźnie obecny był w tekstach publikowanych oraz w wystąpieniach malarza na falach polskiej sekcji radia BBC.

Szanowni Państwo, Drodzy Studenci, nie mogłem oprzeć się pokusie, by nie przywołać — być może zbyt długiego, ale cennego - fragmentu nagrania, jakie znalazłem kilka lat temu w jednym $\mathrm{z}$ archiwów londyńskich, $\mathrm{z}$ zarejestrowaną audycją z udziałem artysty we wspomnianym radiu BBC.

Znałem już ciebie wiele lat, ale dopiero niedawno dowiedziałem się, że urodziłeś się w Rzymie. Czy jesteś wobec tego typowym kosmopolitą? - pytał Żuławskiego rok przed śmiercią artysty Jerzy Biliński. — Człowiek dojrzewa odpowiedział artysta. - Dojrzewa także do swojej przynależności wewnętrznej. Rozpoznaje źródła. Rozpoznaje te jakieś cechy, które go wiążą z czymś. Są tego różne objawy. Wiem, że jeśli przyjeżdżam do Zakopanego, gdzie się wychowałem, to przyjeżdżam — do ojczyzny. Jak przyjeżdżam na Krupówki, jak jestem w Hali Gąsiennicowej czy w Dolinie Pięciu Stawów, to jestem w ojczyźnie, i co do tego — nie mam żadnych wątpliwości. Dotknięcie ziemi tamtej, stawia mnie — na nogi. Czuję się lepszy, zdrowszy, młodszy, piękniejszy. Właśnie tam. I dlatego coraz bardziej rozumiem swoją polskość. Wiem, że ona jest biologiczna. Że należy to szanować. To, że jak przyjechałem do Londynu, to starałem się całkowicie zatrzeć ślady i uważałem, że whisky i gin są jedynymi napojami - to mi przeszło. Dzisiaj bardzo chętnie — piję wódkę. Wolę ją od wszystkich innych napojów. Także najpierw pisałem po angielsku, bo uważałem, że skoro mieszkam w Anglii, to powinienem pisać po angielsku. 
To jest oczywiście logiczne. Ale — ja wolę pisać — po polsku, bo mój język polski jest soczystszy, niż mój język angielski. Jakkolwiek nie mam żadnych trudności, to jednak z jakichś głębszych źródeł wynika moja polskość — niż angielskość. Ze źródeł — ważniejszych ${ }^{8}$.

Szanowni Państwo, przy zachowaniu naukowych obiektywnych kryteriów, uwzględniających przede wszystkim cały europejski i światowy dorobek w zakresie sztuk plastycznych XX w., na podstawie dotychczasowych badań prowadzonych przede wszystkim w UMK, możemy stwierdzić (a dzisiaj przywołaliśmy dorobek i sylwetki zaledwie kilku malarzy), że polscy artyści plastycy w Londynie — których twórczość pozostaje prawie nieobecna w polskiej historii sztuki XX w., trwając i tworząc poza ojczyzną, udowodnili, że sztuka polska nie kończyła się na Odrze i Nysie Łużyckiej. Że rozwijała się w warunkach wolności poza granicami kraju. Swoimi dokonaniami - dużo wcześniej, zanim runął mur berliński, twórcy polskiego Londynu, obalili twierdzenie głoszone przede wszystkim przez PRL-owską propagandę i krytykę, „że sztuka - jak pisał Stanisław Frenkiel - tworzona przez Polaków na emigracji, pozbawiona kontaktu z ojczyzną, skazana jest na uwiąd lub wynarodowienie"9.

Naszym zadaniem zaś, a może przede wszystkim Waszym — Drodzy studenci, jest przywrócenie sztuce polskiej powstałej poza Polską, należnego jej miejsca w dziejach historii sztuki minionego stulecia. Przede wszystkim — poprzez odważniejsze i szersze, otwarcie drzwi do poczekalni, w której nadal ją przetrzymujemy.

Jan W. Sienkiewicz (Toruń)

\footnotetext{
${ }^{8}$ Kopia nagrania z 1985 r. - w posiadaniu autora.

${ }^{9}$ S. Frenkiel, Polskie malarstwo i rzézba w Wielkiej Brytanii 1945-1985, [w:] Polskie więzi kulturowe na obczyźnie, pod red. M. Paszkiewicza, Londyn 1986, s. 118 („,Prace Kongresu Kultury Polskiej", t. 8).
} 